Contents available at: Sri Lanka Journals Online

\title{
Trends and Patterns of Processed Food Exports from South Asia: An Analysis of Product and Market Diversification
}

\author{
S. Sahibzada ${ }^{1}$, D. Hemachandra ${ }^{2}$, S.A. Weerasooriya ${ }^{2}$ and J. Weerahewa ${ }^{2}$ \\ ${ }_{1}^{1}$ Postgraduate Institute of Agriculture, University of Peradeniya, Peradeniya, Sri Lanka. \\ ${ }^{2}$ Department of Economics and Business Management, Faculty of Agriculture, University of Peradeniya, Peradeniya, Sri \\ Lanka.
}

\section{ARTICLE INFO}

\section{Article history:}

Received: 14 August 2019

Accepted: 11 November 2019

Revised version received: 13 June 2020

Available online: 1 October 2020

\section{Keywords:}

South Asia

Processed Food

Export Diversification

Extensive Margin

Intensive Margin

\section{Citation:}

Sahibzada S., Hemachandra D.,

Weerasooriya S.A. and Weerahewa J.

(2020). Trends and Patterns of Processed

Food Exports from South Asia: An

Analysis of Product and Market

Diversification. Tropical Agricultural

Research, 31(4): 65-90

DOI: http://doi.org/10.4038/tar.v31i4.8422

Sahibzada S. (iD

https://orcid.org/0000-0002-8246-0072

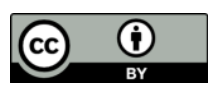

\begin{abstract}
Expansion of processed food exports through diversification of products and markets is one of the key development strategies adopted by several developing countries, and South Asia is no exception. The objective of this study was to describe the trends and patterns of export diversification of processed food by Bangladesh, India, Pakistan, and Sri Lanka during 2001 - 2017. The degree of product and market diversification of processed food was measured using the Herfindahl-Hirschman index employing UN Comtrade data using SITC (Revision 2) classification at the 4-digit level. The analysis conducted on global demand for processed food revealed that meat products, animal and vegetable oils, margarine, prepared food, and bakery and dairy products were in high demand and the USA, Germany, China, UK, and France are the major importers. The analysis conducted on the supply of processed food by the South Asian countries revealed that the composition of processed food export baskets has changed in Bangladesh and Sri Lanka from minimally processed levels to moderately and highly processed levels. Moreover, it was found that Bangladesh has significantly diversified processed food exports at the product level. Sri Lanka has steadily diversified its export markets in recent years whereas Bangladesh, India, and Pakistan showed a decline in market diversification. The Ansoff Matrix illustrated that all four countries have been successful in acquiring new markets and exporting new products over the period under consideration and diversification occurred both at the extensive and intensive margins.
\end{abstract}

*Corresponding author : sara.sahibzada.fazli@gmail.com 


\section{INTRODUCTION}

International trade has often been called the "engine of growth" of economies. Historically, periods of rapid growth in international trade have corresponded with periods of rapid economic growth. International trade can lead to alleviation of poverty, private sector development, employment creation, and women empowerment (WBG and WTO, 2018). In addition, it can also prompt innovation, access to new technology (UNESCAP, 2018), lower commodity prices, and increase choices (Francois et al., 2007). It enhances wider access to inputs with lower cost, higher productivity, increased competition, and investment (Alcalá and Ciccone, 2004).

The nature and size of gains from trade are context-specific. It has been observed that countries at their early stages of development tend to depend on trade in primary products and they rely more on manufacturing products as they move away from the early stages of development. Expansion of exports in the manufacturing sector is associated with job creation (Kaplinsky, 2011) compared to that of primary commodities which have a limited scope for developing forward and backward linkages. Thus, from a long-term perspective, the prospects of raising future revenue from the export of primary commodities and fostering economic growth are limited and lesser than gain from manufacturing products. Processed food, which has characteristics of both primary and manufacturing products, are potential products for countries in economic transition to reap gains from trade.

Important changes have been observed in the global processed food trade in recent decades (Athukorala, 1998; Wilkinson, 2006; Baker et al., 2016). The processed food industry in developing countries is extensive, due to the rapid growth of cities, changes in population, and rapid growth in supermarkets and new retail outlets (McKay, 2007). According to Athukorala and Sen (1998), Chile, Indonesia, Turkey, Tunisia, Guatemala, El Salvador, and Sri Lanka have been at the forefront in the increase of processed food in their share of total non-manufactured exports by mid1990s. The successful expansion of processed food exports is considered a key factor contributing to this impressive performance by Chile. Currently, Chile has a modern and developed food processing industry that represents $25 \%$ of its economy with annual sales of $\$ 34$ billion (USD) and a 10\% annual growth in 2018 (Herrera, 2019). The Chilean economy could serve as a model for other developing countries in this context (Edwards, 1995).

Developing South Asian countries endowed with agriculture, livestock, and marine resources have also begun to benefit from this phenomenon. This region has a history of being primary product exporters and hence moving to processed food exports would be timely and appropriate. The objective of this paper is to describe the trends and patterns of export diversification of processed food by Bangladesh, India, Pakistan, and Sri Lanka during 2001 - 2017.

This paper is organized as follows. The second section presents the theoretical and empirical framework. The third section provides a contextual background of processed food in South Asia. The subsequent sections present results for market diversification of processed food in each South Asian country and the results of product diversification for processed food in South Asia. The last section consists of conclusions and recommendations.

\section{THEORETICAL AND EMPIRICAL FRAMEWORK}

\section{Export diversification: Theory and concept}

Diversification is a fundamental concept in economics and financial decision making. There is not a standard definition of export diversification in literature. Conceptually, the definition is derived from the way it is measured. In the majority of studies, concentration indices are used as a measure of export diversification concerning the products and markets. Therefore, diversification can be defined as the change in inequality between export shares, and it is a 
result of the introduction of new export products or partners in the extensive or intensive margin. On the other hand, when a country's exports are comprised of a large number of products and/or with a larger number of trading partners, it is said to have diversified exports. Export diversification aims at mitigating economic and political risks by reducing the dependence upon one/a limited number of products and geographical destinations for its exports.

The theory of export diversification can be best explained by the statement "don't put all your eggs in a single basket". Bernoulli in 1738, may have been the first to formally argue for the benefits of diversification. He argued by providing examples that riskaverse investors would want to diversify. The most prominent conceptual theory of diversification is that of Darwin (1859), who expounded that greater diversity of life forms is conducive to a greater level of functioning and higher evolutionary fitness level. Some researchers who tested the effect of diversification and increasing trade (such as Dornbusch et al., 1977), argued that trade will increase if countries diversify their export baskets. Chenery (1979) and Syrguin (1988) claimed, that to achieving sustainable growth, countries should diversify their exports from primary to manufactured products. Ghosh and Ostry (1994), and Bleaney and Greenaway (2001), argued that for some countries which are dependent on commodities with very volatile market prices may suffer from export instability. Therefore, export diversification could help stabilize export earnings in the long-run. One of the endogenous growth models that proposed by Matsuyama (1992) emphasizes the relationship between learning by doing in the manufacturing sector and export diversification, there could be knowledge spill over from new techniques of production, new management, or marketing practices and will help in diversification (Pineres and Ferrantino, 2000). Recent literature mostly highlights the link between export diversification to the process of "selfdiscovery" or innovation (Hausmann and Rodrik, 2002; Klinger and Lederman, 2006).
This strand of literature argues that the discovery of new export products by firms or the government, emphasizes the role of informational externalities related to the process of discovering new exports.

Moreover, a large strand of recent literature evaluated the degree of export diversification in terms of intensive and extensive margin (Amurgo-Pacheco and Pierola, 2008; Ekmen and Erlat, 2013; Islam, 2014; Turkcan, 2014; De Silva, 2014). The intensive margin refers to the measure of the intensity of the set of existing products that are already being exported. The extensive margin can be defined as the growth of exports in new categories. Similarly, we can think about markets. For high export earnings, countries should have a particular export structure, and they have to improve their exports and find new products and the new market at the intensive and extensive levels (De Silva, 2014). The intensive margin of exports and the quantity component of exports is important to factors for export growth (Otamurodov et al., 2016).

\section{Export diversification: Empirical measurement}

Several measures have been developed to estimate export diversification, namely, the Ogive Index, Entropy Index, Concentration Ratio (Cr), Herfindahl-Hirschman Index (HHI), and Aggregate Specialization Index. The HHI was chosen, among other indices, to measure export diversification due to its simplicity and adaptability to different types of export diversifications (products and geographic diversification). It also attributes more weight to products or markets with larger shares by squaring shares before summing them up. This is an important feature that needs to be addressed when measuring diversification since the level of diversification depends on both the number of commodities or markets as well as on the distribution of their shares. In addition, HHI takes into account a large number of products and markets (Pavic et al., 2016). Many have employed HHI as a measure of diversification (Balavac and Pugh, 2016). 
The HHI is a better measure of market concentration as it takes into account all companies (Pavic et al., 2016). The HHI has also been used to analyse the degree of product diversification in Pakistan (Akbar, 2001; Ahmad, 2014) and is used to analyse the export diversification of agriculture products in South Asia (Asian Development Bank, 2015). Furthermore, the HHI has been applied to find export diversification with respect to products and markets in Bangladesh (Hossain and Chowdhury, 2014) and Geneva (Vahalík, 2015). Moreover, product and Market diversification for vegetable and certain other products have been analysed by using HHI with intensive margin in Sri Lanka (De Silva, 2014). Further, the $\mathrm{HHI}$ is the most widely used measure of trade and commodity diversification. Hence, the HHI was selected to analyse products and market diversification in this paper. HHI for market diversification is defined as follows:

$$
H H I=\sum_{d_{i}}^{N_{d}} S_{d_{i}}^{2}
$$

Where Sd_i is the share of total exports attributed to the geographical distance $i$, and $\mathrm{N} \_\mathrm{d}$ is the number of geographical distances. The formula can be reset for product diversification as follows:

$$
H H I=\sum_{c_{i}}^{N_{C}} S_{c_{i}}^{2}
$$

Where $\mathrm{Sc}_{-} \mathrm{i}$ is the share of total exports attributed to the processed food category i, and $N_{-} c$ is the number of processed food categories. The index ranges between 0 and 1 , where 1 reflects the perfect concentration and 0 perfect diversification.Processed food has categorized into 11 groups, details of which are available in appendix 6, whereas geographical destinations were categorized into nine major areas according to the levels of development and regions.

Four South Asian countries (Bangladesh, India, Pakistan and Sri Lanka) were chosen for the study based on the data availability for the years 2001 through 2017. Intraregional trade of processed food between South Asian countries was also studied but data was only available until 2015 for intraregional export values in Bangladesh. The product composition of the export baskets of various countries in the region shows that these four countries contribute to approximately $99 \%$ of the total export of the region. Therefore, these four countries together can be considered as representing trade in South Asia.

For this study, the pattern of diversification was used in the two forms of intensive margin and extensive margin. The concept of the margin is explained by a Product/Market Ansoff Matrix (Figure 1). The intensive margin of export refers to the expansion of exports in goods currently exporting, which is also defined as "market penetration". The extensive margin includes the growth of export items and export destination in at least one category. The threshold will be selected according to the size of a country's exports (Berthou and Vicard, 2013), and hence, $\$ 100,000$ (USD) was chosen as the threshold for finding new markets and new products for processed food exports from South Asian countries following the work of

\begin{tabular}{|c|c|c|c|}
\hline & \multicolumn{3}{|c|}{ Export Products } \\
\hline \multirow{3}{*}{ 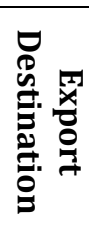 } & & Existing & New \\
\hline & Existing & $\begin{array}{l}\text { Market Penetration } \\
\text { (Intensive Margin) }\end{array}$ & $\begin{array}{l}\text { Commodity Diversification } \\
\text { (Extensive Margin) }\end{array}$ \\
\hline & New & $\begin{array}{l}\text { Market/Destination Diversification } \\
\text { (Extensive Margin) }\end{array}$ & $\begin{array}{c}\text { Complete Diversification } \\
\text { (Extensive Margin) }\end{array}$ \\
\hline
\end{tabular}
Berthou and Vicard (2013).

Figure 1: The dimensions of export diversification.

Sources: Adapted from Hossain and Chowdhury (2014) and Pacheco and Pierola (2007). 


\section{Classification:}

There are different commodity classifications and researchers use them according to the purpose of their research. For this study, to find the product characteristics and their patterns over the said period, all products were classified into two major categories: manufacturing and non-manufacturing. It should be noted that processed food and primary products were included in nonmanufacturing products as shown in Table 1.

Table 1: Classification of major product categories.

\begin{tabular}{|c|c|}
\hline Categories & SITC Classification \\
\hline A-Manufacturing Products & $\begin{array}{l}5-8 \text { less }(68,59222,59212,59225) \\
68=\text { Non-ferrous metals } \\
592=\text { Starch, wheat gluten, albuminoidal substances, and glues }\end{array}$ \\
\hline $\begin{array}{l}\text { B-Non-Manufacturing } \\
\text { B1- Processed Food } \\
\text { B2-Primary products } \\
\text { B3- Others }\end{array}$ & $\begin{array}{l}\text { Total non-oil exports less manufacturing exports as defined } \\
\text { In the ISIC classification are industry groups } 311-314 \text { (list of } \\
\text { processed food products attached in appendix). } \\
\text { Non-manufacturing less processed food and others } \\
\text { Non-manufacturing less processed food and primary products. }\end{array}$ \\
\hline C- Crude Oil & 3 \\
\hline Total Non-Oil & Total products less $\mathrm{C}$ \\
\hline
\end{tabular}

different definitions of processed food, it has been mainly defined as a process of value addition to the agricultural or horticultural products by various methods. In other words, it is a technique of manufacturing and expertly preserving food substances with a view of enhancing their shelf life - improving quality as well as making them more functional. The SITC (Standard International Trade Classification) does not permit the direct identification of processed food products (Athukorala, 1998; Jongwanich, 2009), but the ISIC (International Standard Industry Classification) has a separate section for processed food products. Thus, a map was prepared to identify processed food products by using the SITC Revision 2 at the 4-digit level to that of the ISIC Revision 2 at 4-digit level (all commodities that belong to ISIC Section 3 were classified as processed food). Furthermore, the Harmonized Standard (HS) at the 6-digit level, in line with the United Nations Commodity Concordance was also employed. According to this map, processed food was categorized into 11 major groups (1. meat products, 2 . dairy products, 3 . processed fish products, 4. preserved fruits and vegetable, 5. margarine and food preparation,
6. flour and cereals, 7. animal oils and vegetable oils, 8 . sugar and molasses, 9. coffee extracts and chocolate, 10 . bakery products, 11. beverages) for demonstrating composition change in a specific period. Data were downloaded from the UN Comtrade database.

\section{TRENDS IN GLOBAL DEMAND FOR PROCESSED FOOD AND EXPORT PERFORMANCE OF SOUTH ASIA}

This section illustrates the types of processed food categories that have a high demand, the major importers of South Asia and the world's processed food trade, and the significance of the processed food trade to major South Asian countries.

\section{Global demand for processed food}

The global demand for processed food was $\$ 805$ billion in 2017, and it was more than a threefold increase from $\$ 246$ billion (USD) in 2001, owing mainly to the growing world population, soaring urbanization, changing lifestyles, increasing purchasing power, rising numbers of working women, and a greater 
willingness to experiment with new products (Baker and Friel, 2014).

USA was the leading importer of majority of processed food categories with imports valued at $\$ 26.2$ billion $(11 \%$ of global imports) in 2001, increasing over time to $\$ 81$ billion (12\% of global imports) in 2017 (Figure 2). Japan, China, and the USA were the major importers of meat products, with India being the major importer of animal and vegetable oils. Germany was a chief importer of preserved fruit and vegetable and high value-added products such as sugar, molasses, and coffee. Moreover, developed countries were significant importers of highly processed products such as sugar, molasses, bakery products, beverages, and food of animal origin, while developing countries were importers of minimally and moderately processed food (Table 2). Processed food has doubled in consumption in high-income countries compared to middle-income countries. Both have increased in consumption, at a faster rate in middleincome countries (Monteiro et al., 2013).
Global Demand for Processed Food by Country in 2017

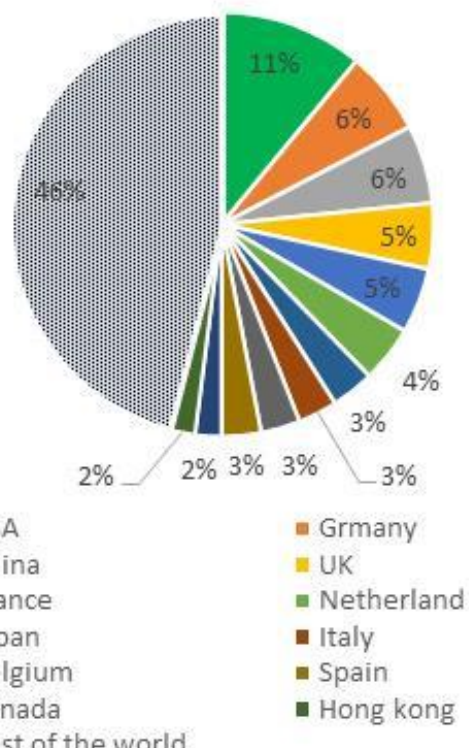

Global Demand for Processed Food by Major Catagories in 2017

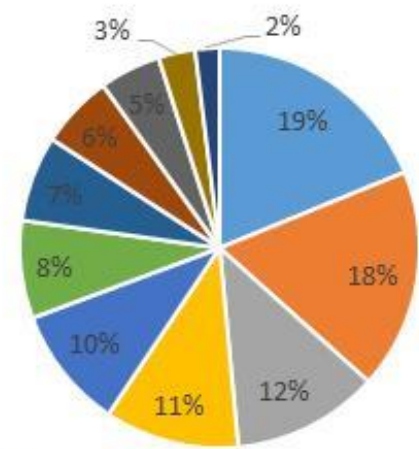

- Meat Production

- Animal oil \& Vegetable oil

- Margar in \& Food Prepration

= Bakery Products

- Dairy Products

- Beverage

- Processed Fruits and Vegetables

- Coffe extract

- Flour and Cerial

- Sugar \& Molasses

- Processed Fish

Figure 2: Global demand for processed food by major importers and major product categories. Source: Author Calculations Based on UN Comtrade data.

\section{An overview of processed food export performance in South Asia}

Processed food products were the main focus of this study. Although there are different definitions of processed food, it has been mainly defined as a process of value addition to the agricultural or horticultural products by various methods. In other words, it is a technique of manufacturing and expertly preserving food substances with a view of enhancing their shelf life - improving quality as well as making them more functional. The
SITC (Standard International Trade Classification) does not permit the direct identification of processed food products (Athukorala, 1998; Jongwanich, 2009), but the ISIC (International Standard Industry Classification) has a separate section for processed food products. Thus, a map was prepared to identify processed food products by using the SITC Revision 2 at the 4-digit level to that of the ISIC Revision 2 at 4-digit level (all commodities that belong to ISIC Section 3 were classified as processed food). 
Table 2: Percentage share of major importers of processed food categories in 2017.

\begin{tabular}{|c|c|c|c|c|c|}
\hline \multirow{3}{*}{$\begin{array}{l}\text { Categories } \\
\text { Meat } \\
\text { manufacturing }\end{array}$} & \multicolumn{5}{|c|}{ Major Importers } \\
\hline & Importers & Japan & China & USA & Germany \\
\hline & Share\% & 9 & 7 & 7 & 6 \\
\hline \multirow{2}{*}{ Dairy products } & Importers & Germany & China & Netherland & France \\
\hline & Share\% & 10 & 6 & 5 & 5 \\
\hline \multirow{2}{*}{$\begin{array}{l}\text { Processed fish } \\
\text { products }\end{array}$} & Importers & USA & Japan & Italy & Germany \\
\hline & Share $\%$ & 16 & 8 & 7 & 6 \\
\hline \multirow{2}{*}{$\begin{array}{l}\text { Preserved Fruits } \\
\text { and vegetables }\end{array}$} & Importers & USA & Germany & France & Japan \\
\hline & Share $\%$ & 14 & 9 & 7 & 6 \\
\hline \multirow{2}{*}{$\begin{array}{l}\text { Margarine and food } \\
\text { preparation }\end{array}$} & Importers & USA & France & UK & Germany \\
\hline & Share\% & 7 & 6 & 5 & 5 \\
\hline \multirow{2}{*}{ Flour and cereals } & Importers & China & USA & Saudi Arabia & Iraq \\
\hline & Share $\%$ & 6 & 5 & 4 & 4 \\
\hline \multirow{2}{*}{$\begin{array}{l}\text { Animal oil and } \\
\text { vegetable oil }\end{array}$} & Importers & India & China & USA & Netherland \\
\hline & Share $\%$ & 9 & 7 & 6 & 6 \\
\hline \multirow{2}{*}{ Sugar and molasses } & Importers & USA & Germany & Italy & Mexico \\
\hline & Share\% & 6 & 4 & 4 & 3 \\
\hline \multirow{2}{*}{$\begin{array}{l}\text { Coffee extract and } \\
\text { chocolate }\end{array}$} & Importers & USA & Germany & France & UK \\
\hline & Share\% & 12 & 9 & 7 & 6 \\
\hline \multirow{2}{*}{ Bakery production } & Importers & USA & China & Germany & UK \\
\hline & Share\% & 11 & 9 & 7 & 6 \\
\hline \multirow{2}{*}{ Beverages } & Importers & USA & UK & Germany & China \\
\hline & Share\% & 21 & 7 & 7 & 6 \\
\hline
\end{tabular}

Source: Author calculations based on Trade Map data

The USA was the leading importer of the majority of processed food categories with imports valued at $\$ 26.2$ billion (11\% of global imports) in 2001, increasing over time to $\$ 81$ billion (12\% of global imports) in 2017 (Figure 2). Japan, China, and USA were the major importers of meat products, with India being the major importer of animal and vegetable oils. Germany was a chief importer of dairy products. As Table 3 depicts, the export of manufacturing products occupy a large proportion compared to other product categories, and it is on the rise in all South Asian countries except Pakistan. However, processed food exports have grown faster than other primary product exports though growth has still been slower than manufacturing product exports. This is a result of the rapid expansion of parts and component trade underpinned by the broader process of product fragmentation (Athukorala and Jayasuriya, 2005). Processed food occupies $62 \%$ of total nonmanufacturing exports in Pakistan. Interestingly, Afghanistan is a major export market for Pakistan and the former has created a high demand for processed products such as wheat flour and processed 
cereals. Therefore, $70 \%$ of the processed food export composed of wheat flour and processed rice (Table 4).

According to Figure 3, Bangladesh showed an impressive growth in processed food exports until 2014 due to its agricultural base, low labour cost, and government support (Hossain and Chowdhury, 2014), which however has declined resulting from nontariff barriers imposed by its developed and developing countries (Latif et al., 2015).

India and Sri Lanka have shown an upward trend in processed food exports over the last 17 years, while Pakistan has experienced a slightly decreasing trend in the share of processed food exports over the specified time period. According to the Pakistani Report of Commerce (2015), the export of manufacturing products (including processed food) decreased due to non-quantifiable factors such as lack of export products and market diversification, non-compliance of quality standards, poor market access, poor trade facilitation, and low levels of technological advancement. This list also covers quantifiable factors, namely, lack of foreign direct investment, high-interest rates, inflation, and high average applied tariff rates. As a whole, various factors such as income, the communications revolution, international tourism etc. have provided a significant demand-side impetus to the growth of processed food exports from this region (Athukorala, 1999). On the supplyside, improvements in food technology, refrigeration facilities, and transportation have made processed food items easily tradable across national boundaries.

\section{Composition of processed food export basket}

Table 4 shows that the composition of processed food exports in Bangladesh has changed from flour, cereal preparation, and bakery products to export of preserved fruit and vegetable and bakery products during the 2001-2017 period. Fruit and vegetable juices were the major products of this group (Appendix 1).
Flour and cereal preparation and animal/vegetable oils were significant categories that have been exported from India which have later been replaced by meat products in the 2001 to 2017 period. While bovine and sheep meat has contributed to $96 \%$ of India's meat product exports, custard oil was an important oil product in 2017 (Appendix 2).

Though over $70 \%$ of the composition of processed food in Pakistan was flour and cereal preparation, it has switched to meat products from 2001 to 2017 (Table 4). Wheat flour and milled rice were dominant products and were primarily exported to Afghanistan and Kenya (Appendix 2).

Animal/vegetable oils, flour, cereal, and food preparation were prime processed food categories that were exported from Sri Lanka in the 2001-2017 period. Conversely, food preparation, flour, and cereal preparation have increased and animal/vegetable oils have declined by 23 percent. Coconut oil contributed to $77 \%$ of Sri Lanka's oil export in 2017 (Appendix 2).

Over the past 17 years, there has been a notable shift in the composition of the structure of the processed food export basket from minimally and moderately processed to highly processed products, in all countries in South Asia except Pakistan.

\section{RESULTS AND DISCUSSION}

\section{Market diversification of processed food in South Asia}

This section presents the market diversification of processed food in India, Bangladesh, Pakistan and Sri Lanka individually. Trends of market diversification have been estimated by the HHI in the 20012017 period.

\section{Market diversification of processed food in Bangladesh}

Since early 2001, the importance of the G3 markets (European Union [EU], Japan, and the USA) has declined and developing 
countries* have become more important for Bangladesh's processed food exports. This pattern is increasing over time due to change on the side of demand in these countries (Chart 3, Figure 4). Saudi Arabia, the United Arab Emirates (UAE), and Malaysia accounted for $48 \%$ of the total of Bangladesh's processed food in 2015 (Chart 2, Figure 4). Somalia, Saudi Arabia, and UK were the major importers of Bangladesh's preserved fruit, vegetable, flour, and bakery products in 2017 (Appendix 1).

Bangladesh has found 35 new markets in 2017 in comparison to 2001. India, Oman, Qatar, Vietnam, and USA were the major new markets for Bangladesh's processed food and therefore, Bangladesh has an extensive margin in the case of markets. According to Figure 8, the HHI index had declined until 2010 but increased since then. Export markets of Bangladesh show that they were more diversified prior to 2010, which may have been a result of increased intraregional exports from $3 \%$ to $11 \%$. Meanwhile, exports to India has increased by 59 percentage point (Appendix 5) due to a land boundary agreement in 2015 that opened new relationships, stopping irritants in ties between Bangladesh and India (Banerjee et al., 2017). In addition, Hossain and Chowdhury (2014) found that the expansion of new export markets or destination is the main reason for the improved export diversification in Bangladesh, and the result of this improvement is export growth.

\section{Market diversification of processed food in India}

As Figure 5 illustrates, processed food exports from India to developing countries have increased, while exports to developed countries have decreased over time. While the USA, Malaysia, and UAE were major importers of India's processed food in 2001, these countries soon lost their importance: Vietnam was the most important export partner of India's processed food with a $24 \%$ export share in 2017. This could be due to a Free Trade Agreement between India and Vietnam in 2007. At present, India is among the top ten trading partners of Vietnam. Moreover, Malaysia, Iran, and China were major importers of India's bovine meat, milled rice, and castor oil by 2017 (Appendix 2).

India has found 34 new markets in 2017 since 2001, while Sudan, Libya, Haiti, and Guinea were major new markets for its processed food products. As per the Ansoff Matrix, India has an extensive margin in the case of markets due to new relationships. Though exports to Nepal have increased from $4.7 \%$ to $33 \%$ as a consequence of the India-Nepal Foreign Treaty of Trade Agreement signed in 2009 (Appendix 5), India has decreased its processed food exports to South Asian countries from $12 \%$ to $5 \%$ during the 2001 2017 period. Figure 7 demonstrates that the HHI was less than 0.5. Thus, India has a good market diversification, but the former saw a slightly decreasing market diversification trend during the 2001-2017 period, due to lack of sufficient financial facilitates, frequent changes in tax rates, high transaction costs, lack of knowledge about the government assistance programs, and comprehensive market information (Progress Harmony Development, 2015).

\section{Market diversification of processed food in Pakistan}

South Asian countries especially Afghanistan were major importers of Pakistan's processed food: over 50\% of Pakistan's total processed food was imported by Afghanistan in 2017 (Figure 6). This could be due to various reasons. First, several Free Trade Agreements between the countries such as the "Afghan Transit Trade Agreement (ATTA) of 1965" and the "Afghan-Pak Transit Trade Agreement (APTTA) signed in 2010" between the two countries.

\footnotetext{
* Developing and developed countries were identified from the UN Comtrade country classification.
} 
Table 3: Merchandise exports by major categories from South Asia.

\begin{tabular}{|c|c|c|c|c|c|c|c|c|}
\hline \multirow[b]{2}{*}{ Categories / Years } & \multicolumn{2}{|c|}{ Bangladesh } & \multicolumn{2}{|c|}{ India } & \multicolumn{2}{|c|}{ Pakistan } & \multicolumn{2}{|c|}{ Sri Lanka } \\
\hline & $\begin{array}{l}2001- \\
2008\end{array}$ & $\begin{array}{l}2009- \\
2017\end{array}$ & $\begin{array}{l}2001- \\
2008\end{array}$ & $\begin{array}{l}2009- \\
2017\end{array}$ & $\begin{array}{l}2001- \\
2008\end{array}$ & $\begin{array}{l}2009- \\
2017\end{array}$ & $\begin{array}{l}2001- \\
2008\end{array}$ & $\begin{array}{r}2009 \\
2017\end{array}$ \\
\hline Total Non-Oil Exports (Million US\$) & 6,173 & 6,343 & 37,693 & 35,727 & 8,627 & 8,798 & 5,284 & 5,333 \\
\hline $\begin{array}{l}\text { Manufacturing as Percentage of Total Non-Oil } \\
\text { Export (A) }\end{array}$ & 92.00 & 95.30 & 78.55 & 77.94 & 85.35 & 77.67 & 71.76 & 69.47 \\
\hline $\begin{array}{l}\text { Non-Manufacturing as Percentage of Total Non- } \\
\text { Oil Export (B) }\end{array}$ & 8.00 & 4.70 & 21.45 & 22.06 & 14.65 & 22.33 & 28.24 & 30.53 \\
\hline $\begin{array}{l}\text { Processed Food as Percentage of Total Non- } \\
\text { Manufacturing }\left(B_{1}\right)\end{array}$ & 3.10 & 11.07 & 26.80 & 31.02 & 64.12 & 61.98 & 8.40 & 10.68 \\
\hline $\begin{array}{l}\text { Primary Products as Percentage of Total Non- } \\
\text { Manufacturing }\left(\mathrm{B}_{2}\right)\end{array}$ & 96.89 & 88.90 & 78.3 & 68.68 & 35.87 & 37.84 & 91.30 & 87.80 \\
\hline $\begin{array}{l}\text { Others as Percentage of Total Non- } \\
\text { Manufacturing }\left(\mathrm{B}_{3}\right)\end{array}$ & 0.01 & 0.03 & 0.10 & 0.30 & 0.01 & 0.18 & 0.30 & 1.52 \\
\hline
\end{tabular}




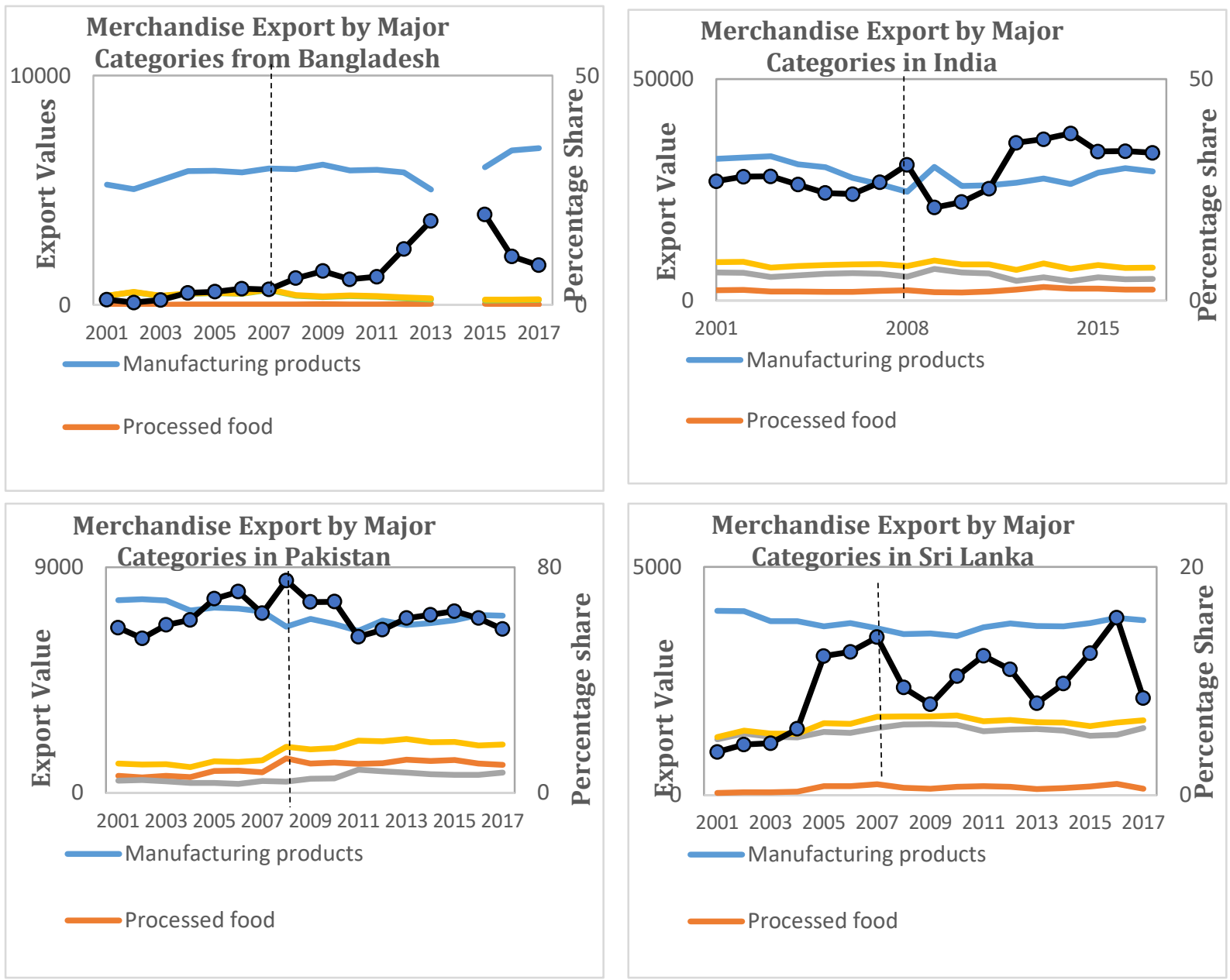

Figure 3: Merchandise exports by major categories in Sri Lanka.

Source: Author calculations based on UN Comtrade data Note: Data was not available for Bangladesh in 2014.

Owing to these agreements, both countries have allowed freedom in transit, and thus Afghanistan is now a major export partner of Pakistan (Sultana, 2011; Attarwala, 2015). Second, Afghanistan faces a deficiency of technology and processed food firms. Consequently, it needs to import from Pakistan. Finally, the commencement of a new political era following the long-time war in Afghanistan has led to an increasing demand for processed food post-2010.

Although Pakistan has an extensive margin in destinations, it was able to find 43 new markets for its processed food (in Serbia, Vietnam, Djibouti, Somalia, Poland, etc.). However, according to Figure 8, as its HHI was over 0.5 , Pakistan is yet to peak in market diversification when compared to other countries in the region. While in recent years some research work have shown a significant relationship between market diversification and GDP growth in Pakistan, they suggest that incentives should be provided to induce Pakistani exporters to find new markets (Forgha et al., 2014; Siddigui, 2018). 
Table 4: The average of processed food exports over time by major product categories (as a percentage of the total processed food).

\begin{tabular}{|c|c|c|c|c|c|c|c|c|c|}
\hline & \multirow[t]{2}{*}{ Products } & \multicolumn{2}{|c|}{ Bangladesh } & \multicolumn{2}{|c|}{ India } & \multicolumn{2}{|c|}{ Pakistan } & \multicolumn{2}{|c|}{ Sri Lanka } \\
\hline & & $\begin{array}{c}2001- \\
2008\end{array}$ & $\begin{array}{c}2009- \\
2017\end{array}$ & $\begin{array}{c}2001- \\
2008\end{array}$ & $\begin{array}{c}2009- \\
2017\end{array}$ & $\begin{array}{c}2001- \\
2008\end{array}$ & $\begin{array}{c}2009- \\
2017\end{array}$ & $\begin{array}{l}2001- \\
2008\end{array}$ & $\begin{array}{l}2009 \\
2017\end{array}$ \\
\hline 1 & Meat manufacturing & 9.56 & 5.64 & 12.27 & 22.12 & 2.89 & 7.53 & 1.37 & 1.59 \\
\hline 2 & Dairy products & 1.80 & 1.15 & 4.81 & 2.57 & 1.24 & 2.30 & 1.48 & 0.96 \\
\hline 3 & Processed fish products & 1.07 & 2.58 & 2.16 & 1.48 & 1.08 & 0.65 & 0.78 & 0.34 \\
\hline 4 & Preserved Fruits and Vegetable & 17.64 & 23.87 & 3.60 & 3.27 & 1.24 & 2.42 & 10.40 & 17.75 \\
\hline 5 & Margarine and food preparation & 8.48 & 3.97 & 4.30 & 4.01 & 1.20 & 1.01 & 13.62 & 23.47 \\
\hline 6 & Flour and cereals & 24.52 & 16.34 & 32.85 & 35.41 & 77.52 & 70.44 & 29.02 & 28.36 \\
\hline 7 & Animal and vegetable oil & 6.79 & 9.41 & 26.77 & 18.84 & 5.56 & 4.16 & 38.34 & 14.94 \\
\hline 8 & Sugar and molasses & 8.23 & 6.60 & 10.33 & 7.84 & 6.15 & 7.61 & 0.54 & 0.52 \\
\hline 9 & Coffee extract \& chocolate & 0.88 & 2.78 & 0.50 & 1.09 & 1.73 & 2.16 & 0.54 & 3.78 \\
\hline 10 & Bakery production & 19.24 & 21.14 & 1.77 & 2.34 & 0.71 & 1.38 & 2.54 & 4.94 \\
\hline \multirow[t]{2}{*}{11} & Beverage & 1.79 & 6.52 & 0.64 & 1.03 & 0.68 & 0.34 & 1.37 & 3.35 \\
\hline & Total & 100 & 100 & 100 & 100 & 100 & 100 & 100 & 100 \\
\hline
\end{tabular}

Source: Author Calculations Based on UN Comtrade data. 


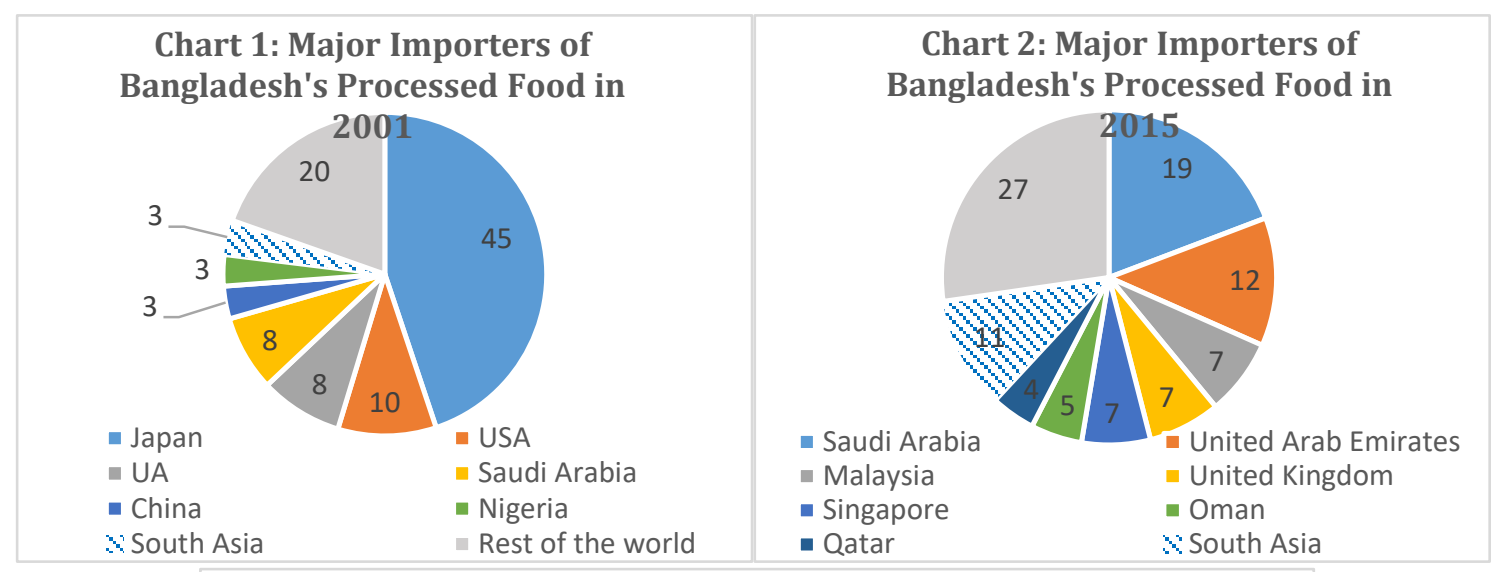

\section{Figure 4: Major export partners of processed food in Bangladesh}

Source: Author calculations based on UN Comtrade data

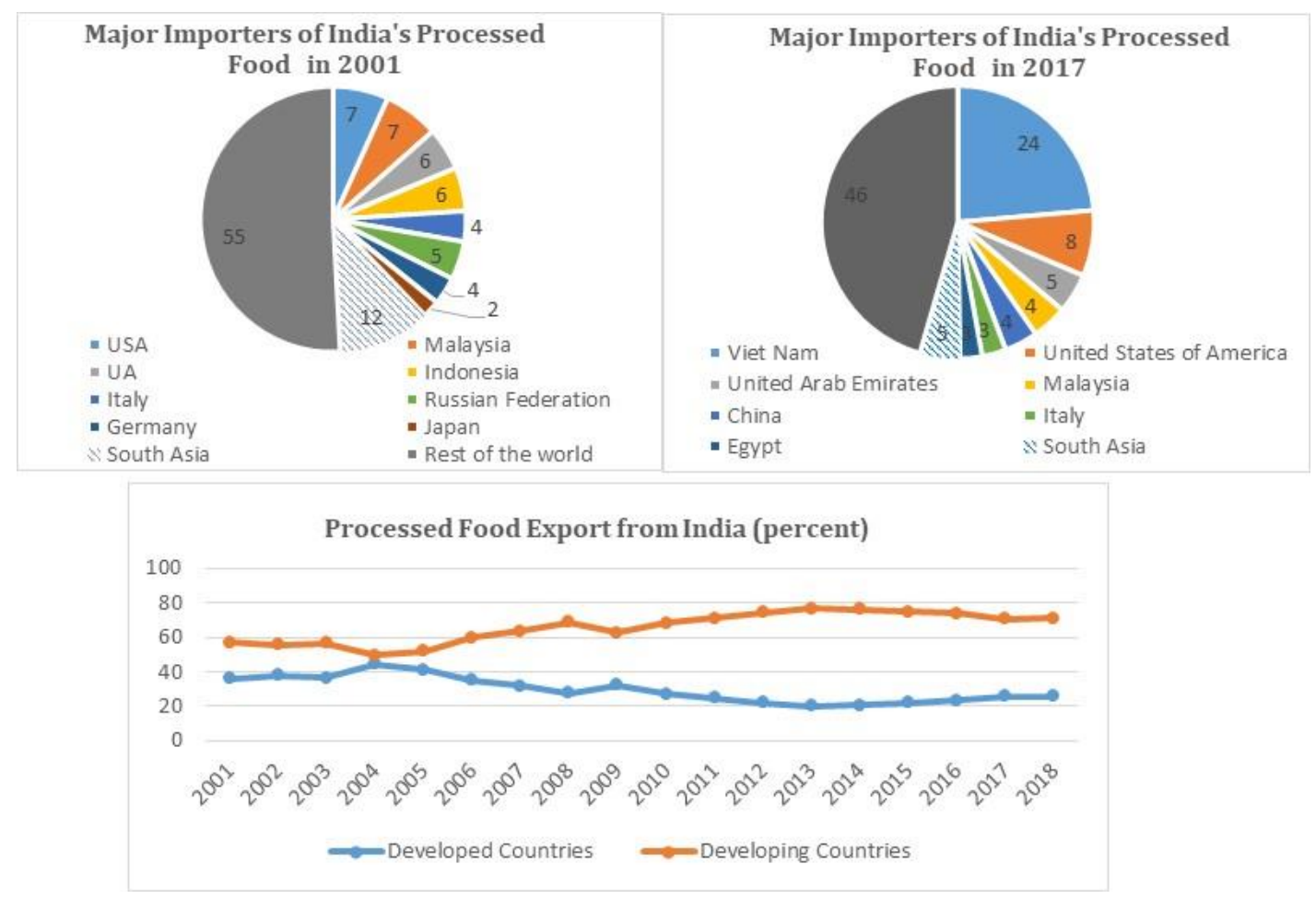

Figure 5: Major export partners of processed food for India.

Source: Author calculations based on UN Comtrade data 


\section{Market diversification of processed food in Sri Lanka}

As Figure 7 illustrates, the USA was a major importer of Sri Lanka's processed food with its contribution doubling over time. Sri Lanka is the only country in the region which has increased its exports to match a developed country in recent years. Sri Lanka has found 53 new markets, and according to the Ansoff Matrix, it has an extensive market margin because the country has new relations with new destinations. Vietnam, Malaysia, Thailand, Ghana, and Sweden were the major new markets for Sri Lanka's processed food in 2017, while Germany, Poland, and Iran were major importers of Sri Lanka's coconut oil in the same year (Appendix 3).

Sri Lanka has decreased in intraregional exports from $14 \%$ to $12 \%$ from $2001-2017$.
According to appendix 5, India, Maldives, and Pakistan were prime importers of Sri Lanka's processed food, whereas exports to India have increased from $21 \%$ to $60.7 \%$ during 2001-2017. This may be a result of the Indo-Sri Lanka Free Trade Agreement (ISFTA) signed in 1998, and taking effect from 2000. According to Figure 8, though the HHI value was more than 0.5 (less diversified) during the 2005-2012 period, it has gained great market diversification in the 2012-2017 era. Sri Lanka is now located in the first position of market diversification among all South Asian countries (Figure 8). Bahavan (2017) also reported that market diversification exists in the structure of export patterns in Sri Lanka and has a longrun relationship with export performance

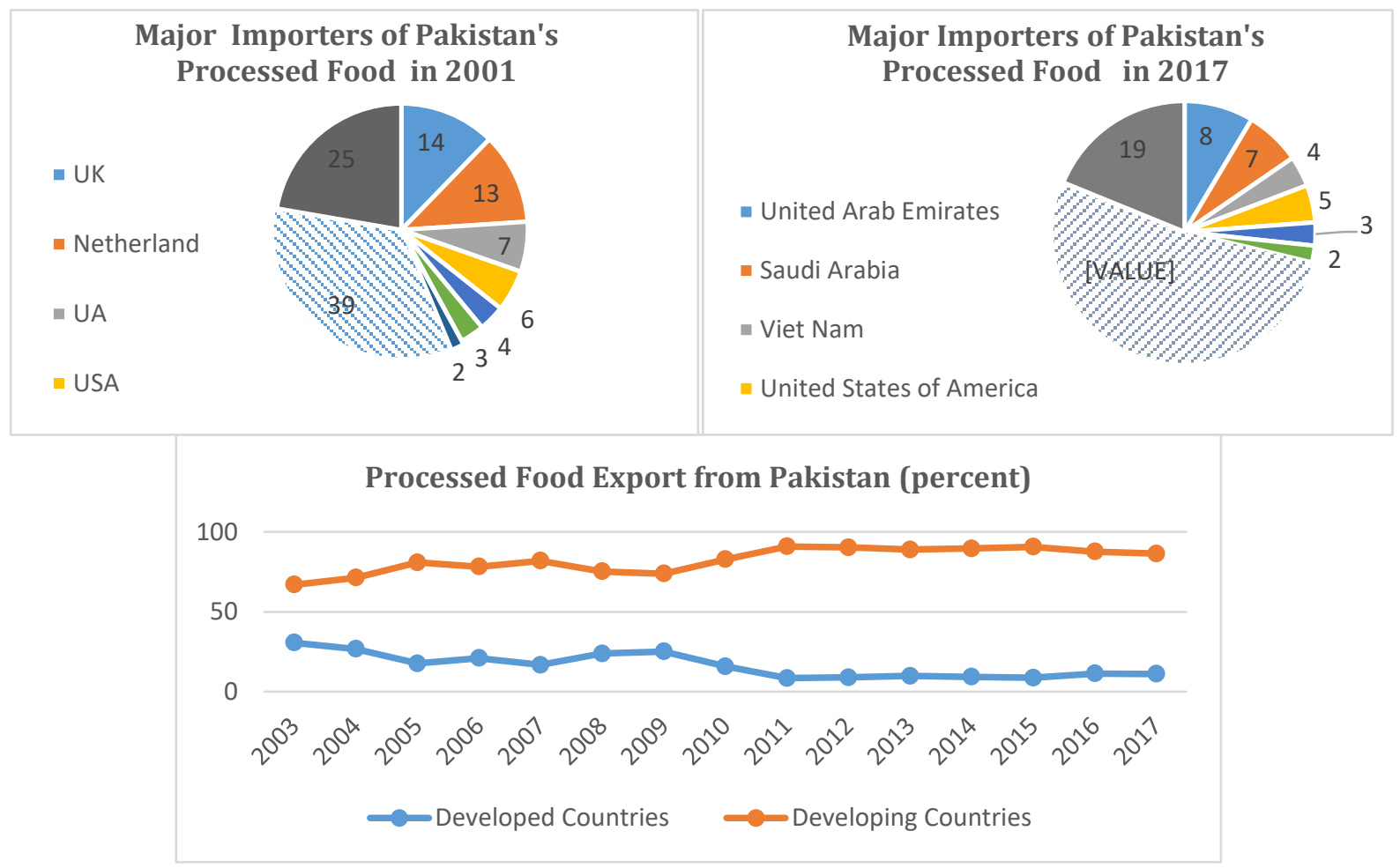

Figure 6: Major export partners of processed food for Pakistan.

Source: Author calculations based on UN Comtrade data 


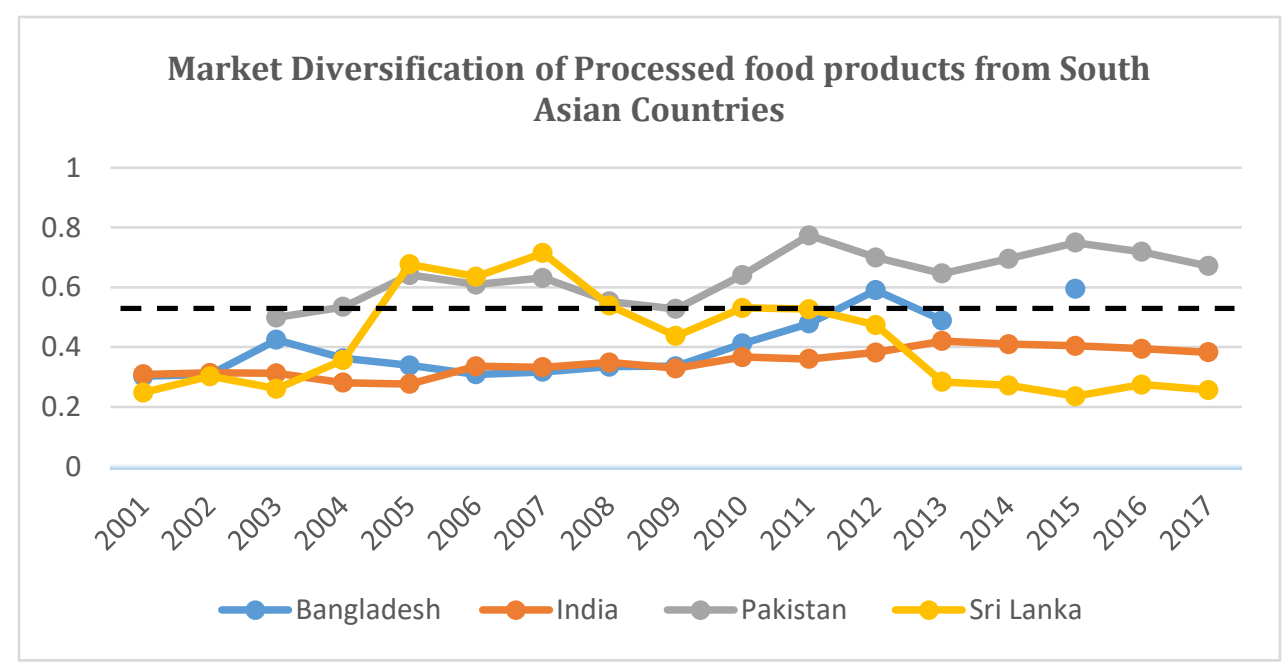

Figure 7: Major export partners of processed food from Sri Lanka.

Source: Author calculations based on UN Comtrade data.

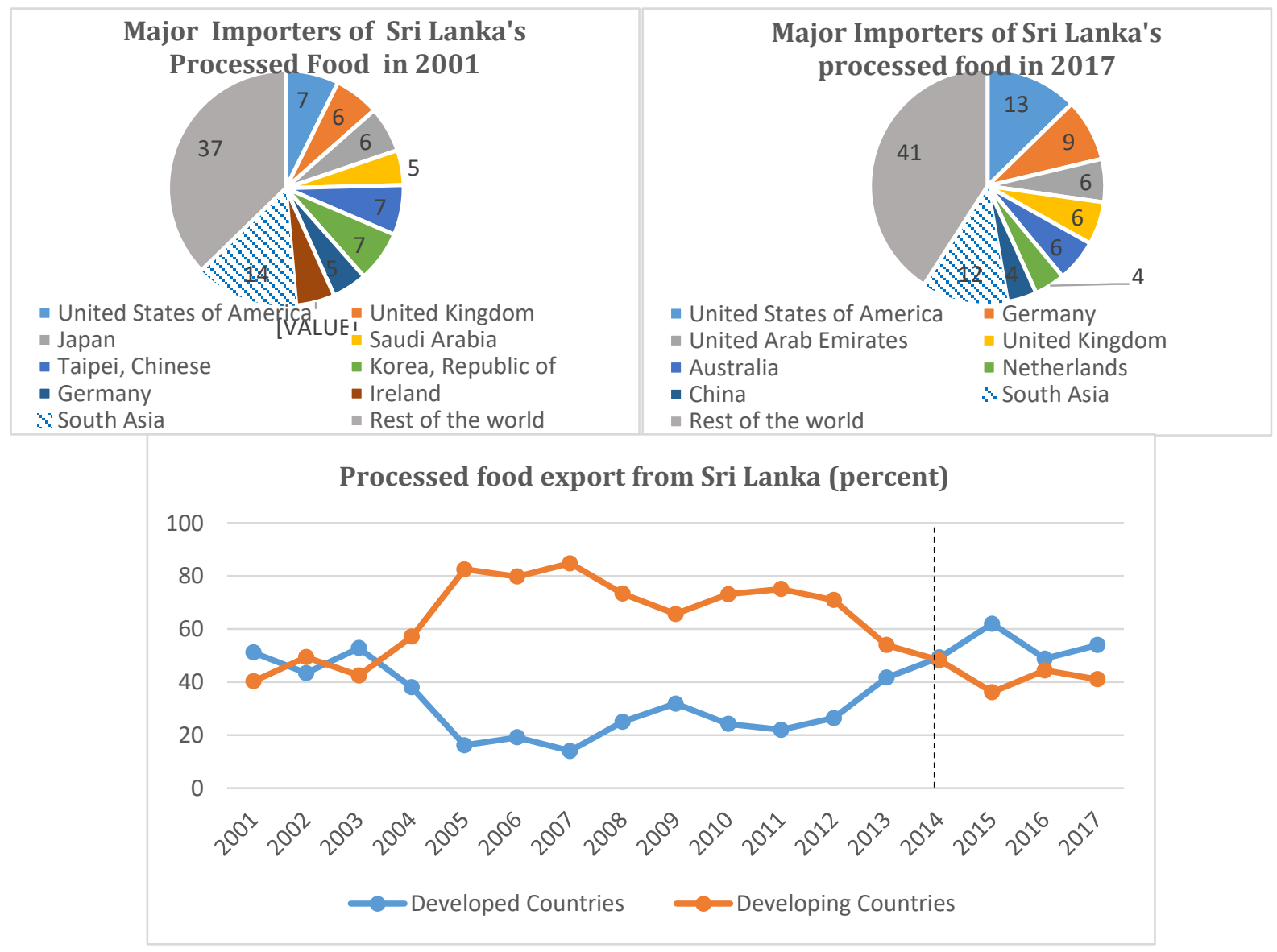

Figure 8: Market diversification of processed food exports from South Asian Countries.

Source: Author calculations based on UN Comtrade data.

Note: Due to the nonavailability of the export data, the Herfindahl Index value has been reported for Bangladesh till 2015. 


\section{Product diversification of processed food}

According to the correspondence of ISIC and SITC, a list of processed food with 11 categories has been provided and as mentioned in the methodology, the export value of $\$ 100,000$ (USD) was selected as the threshold for finding new products. As Figure 9 demonstrates, the HHI for Bangladesh was less than 0.2, showing that Bangladesh has significant product diversification in comparison to other countries in the region with slight fluctuations during the 2001-2017 period. Moreover, it has also diversified its export basket by adding 24 new processed food products, mineral water with additional sugar, preserved crustaceans, pasta, and fruit juices during the specified period. This success in diversifying products may have resulted from the competitiveness in labour cost and government support (Hossain and Chowdhury, 2014).

India has exported 9 new processed food products: groundnut oil, milk, cream, ice cream, and sausages for the year 2017. The $\mathrm{HHI}$ for India was approximately 0.2 with slight fluctuations observed (Figure 9). In terms of product diversification, India is next to Bangladesh. Pakistan exported 18 new processed food products for 2017. Namely, meat flour, bovine meat, frozen vegetables, and cereal groats. While Pakistan had less diversified products when compared with the other countries of the region, it has gained good change by increasing its product diversification. The HHI was nearly 0.7 in 2001 and though it decreased to 0.5 later, it shows that Pakistan has increased diversified products in 2017 in comparison to 2001 (Figure 9).

Similarly, Sri Lanka has exported 15 new processed food products for the year 2017 such as cereal grains, cocoa powder, preserved meat, and vegetables. Although the HHI was nearly 0.2 since 2009 due to adverse domestic conditions, Sri Lanka demonstrated a sharp incline in product diversification beginning in 2005. It increased its product diversification of processed food from 2005-2017. According to the Ansoff Matrix, all four countries have added new products to their export baskets, therefore creating an extensive margin in the case of processed food products.

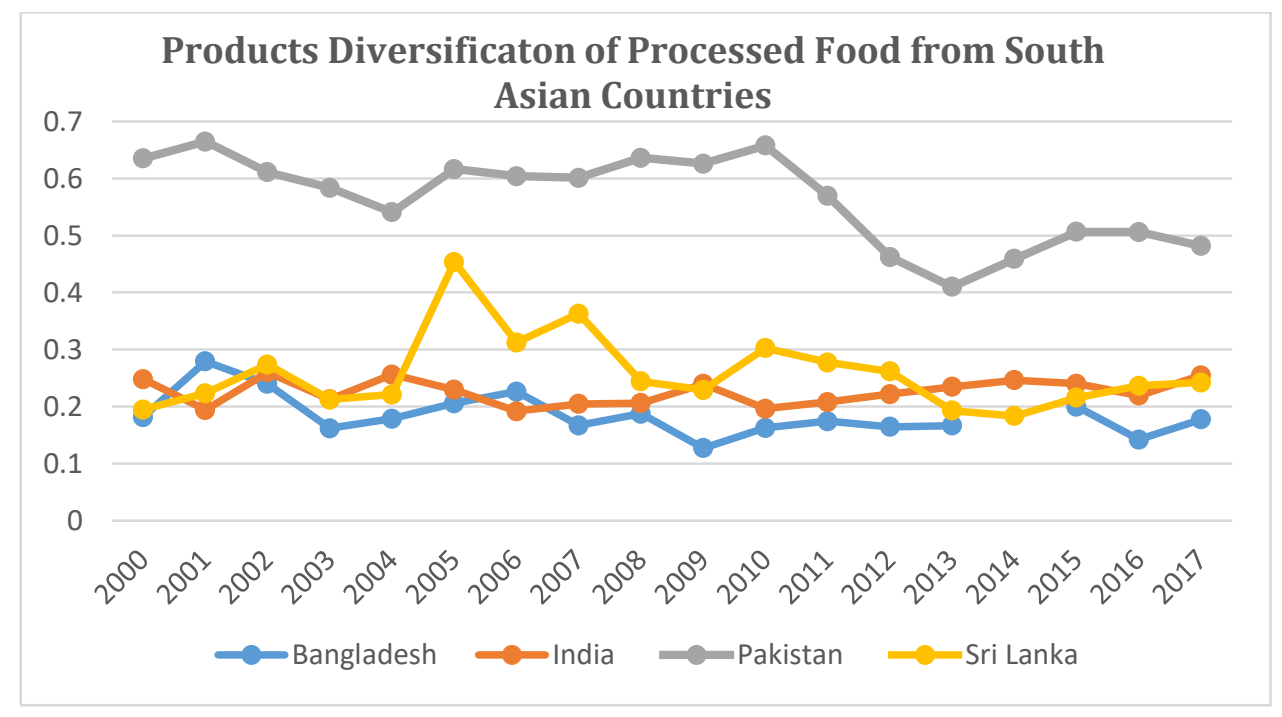

Figure 9: Product diversification of processed food from South Asian countries to the world.

Source: Author calculations based on UN Comtrade data. 


\section{CONCLUSIONS AND RECOMMENDATIONS}

The objective of this study was to describe the trends and patterns of export diversification of processed food by Bangladesh, India, Pakistan, and Sri Lanka during 2001 - 2017. The rise in the share of processed food in non-manufacturing exports shows a significant growth in processed food exports by South Asian countries. India was a substantial exporter of processed food, with Bangladesh on a faster growth rate in processed food export value compared to other countries in the region. Moreover, the export of processed food from total non-oil exports in South Asian countries is very minimal and requires improvement. Non-tariff barriers were the major reason for this condition.

The composition of processed food export baskets has changed in Bangladesh and Sri Lanka from a minimally processed level to a moderately and highly processed level. India brought some change in the composition of processed food export baskets with an increasing share of meat products to touch the global demand, whereas Pakistan holds the same composition of processed food export baskets. Developed countries were major importers of highly processed products like sugar, molasses, bakery products, beverages, and food of animal origin. Conversely, developing countries were major importers of minimally and moderately processed food in line with the differences in income, lifestyle, and attention to food safety and nutritional foods. Market diversification for processed food exports has diversified greatly from 2005 to 2017 in Sri Lanka.

According to the results of HHI, Sri Lanka is currently located in the first position in market diversification followed by India and then Bangladesh. This could be on account of carrying out fiscal reforms, improving public financial management, increasing public and private investments, addressing infrastructure constraints, and improving competitiveness and increasing product diversification (Bahavan, 2017). Product diversification of processed food has increased in South Asian countries with Bangladesh seeing the most success. Moreover, according to the Ansoff Matrix, all four countries have penetrated the market because they have new products and new relations with other destinations in exchange for their processed food products. Thus, these countries have extensive margins in products and market diversification. However, this region still needs to bolster processed food industries to attain more success in product and market diversification and achieve economic growth through processed food exports. Some suggestions can be made as follows in this regard:

1. Highly processed food and animal products: Global demand for highly processed food and animal products is increasing over time. South Asia has exported large quantities of wheat flour and prepared cereal but global demand for bakery products and meat products is more than that for flour. Thus, a policy should provide facilities to change the composition of processed food from minimally processed to highly processed food and meat products. India and Sri Lanka could increase the export of animal and vegetable oils as this product category has a high demand.

2. Sri Lanka has been successful in market diversification, while Bangladesh has seen success in product diversification; thus, other countries in the region can use their experience that will fuel future research and good relationship ties between countries.

3. Even though export basket of Pakistan has occupied with a high percentage of processed food still Pakistan mostly concentrate in export of processed cereals to the neighbouring countries, mostly Afghanistan. Pakistan will gain from export of processed food if it achieves an adequate level of product and market diversification with an intensive and extensive margin.

Developed and developing countries were major markets for processed food products of South Asian countries, while their 
demand for new products is increasing over the year, thus South Asian countries should diversify their products to gain those markets.

\section{REFERENCES}

Ahmed, H. and Hamid, N. (2014). Patterns of Export Diversification: Evidence from Pakistan. The Lahore Journal of Economics. 19, 307-326.

Attarwala, F. and Amir, S.S. (2015). Afghanistan's Transit Trade Patterns Pre \& Post APTTA. Pakistan Business Council (PBC).

Athukorala, P.C. (1998). Processed Food Exports from Developing Countries: Patterns and Determinants. 23(1),4154.

Athukorala, P.C. (1999). Agriculture and the New Trade Agenda in the WTO 2000, Negotiations: Interests and Policy Options for South Asia. The conference on Agriculture and the New Trade Agenda in the WTO 2000 Negotiation. 25- 62.

Athukorala, P.C. and Jayasuriya, S. (2005). Processed Foods Exports from Developing Countries and FoodSafety Related Market Access Issues: Aims and Scope of the Research Project. Background paper prepared for the workshop on International Food Safety Regulation and Processed Food Exports from Developing Countries: A Comparative Study of India and Thailand, Research Information Systems, New Delhi.

Alcalá, A. and Ciccone, A. (2004). Trade and Productivity. The Quarterly Journal of Economics.119 (2), 613646.

Amurgo-Pacheco, A. and Pierola, M. D. (2008). Patterns of export diversification in developing countries: Intensive and extensive margins, World Bank Policy

\section{ACKNOWLEDGEMENT}

This study was carried out with the aid of a grant from the SAARC Agricultural Centre (SAC), Dhaka, Bangladesh.

Research Working Paper No 4473.

Akbar, M. and Naqvi, Z.F. (2001). External Market Conditions, Competitiveness, Diversification, and Pakistan ' $\mathrm{s}$ Export Performance. The Pakistan Development Review. 40(4), 871-84.

Asian Development Bank. (2015). Food Security In South Asia: Developing Regional Supply Chains For The Food Processing Industry. United Nations Conference on Trade and Development.

Baker, P. and Friel. S. (2014). Processed foods and the nutrition transition: evidence from Asia. Obesity Reviews. DOI: 10.1111/obr.12174.

Baker et al. (2016). Trade and investment liberalization, food systems change and highly processed food consumption: a natural experiment contrasting the soft drink markets of Peru and Bolivia. Globalization and Health. 12(1), 24.

Balavac, M. and Pugh, G. (2016). The link between trade openness, export diversification, institutions and output i in transition countries. Economic Systems. 40(2), 273-287.

Banerjee, S. Guha, A. Chaudhury, A.B.R. (2017). The 2015 India-Bangladesh Land Boundary Agreement: Identifying Constraints and Exploring Possibilities in Cooch Behar. ORF, Observer Research Foundation. 117.

Berthou, A. and Vicard, V. (2013). Firms' Export Dynamics Experience vs. Size. The Competitiveness Research Network. Working paper, No. 1616. 
Bhavan, T. (2017). Export market diversification and export performance of Sri Lanka: A cointegration analysis. Asian Journal of Empirical Research. 7(4), 75-83.

Bleaney, M. and Greenaway, D. (2001). The impact of terms of trade and real exchange rate volatility on investment and growth in sub-Saharan Africa. Journal of Development Economics. 65(2), 491-500.

Chenery, H. (1979). Structural Change and Development Policy. Washington, DC: World Bank.

Dornbusch, R., Fischer, S., and Samuelson, P. A. (1977). Comparative advantage, trade, and payments in a Ricardian model with a continuum of goods. The American Economic Review, 67(5), 823839.

Development, Progress Harmony. (2015). India's Exports Diversification Crisscross Outcomes. PHD Research Breau of PHD Chamber: 1-27.

De Silva, H.N. (2014). Export diversification and intensive margin of processed food exports in Sri Lanka. Third Annual Research Conference, ARC.

Edwards, S. (1995). Crisis and Reform in Latin America: From Despair to Hope. Oxford University Press, New York.

Ekmen, S. and Erlat, G. (2013). Export diversification and competitiveness: Intensive and extensive margins of Turkey. Ekonomik Yaklasim. 24(88), 3564.

Forgha, N.G., Sama, M.C. and Atangana, E.M. (2014). The Effect of Export Diversification on Economic Growth in Cameroon. International Invention Journal of Arts and Social Sciences. 1(3), 54-69.

Francois, J., Manchin, M. and Norberg, H. (2007). Passing on of the benefits of trade openness to consumers. European Commission, DirectorateGeneral for Trade. pp, 7.

Ghosh, A.R. and Ostry, J.D. (1994). Export instability and the external balance in developing countries. Staff Papers. 41(2), 214-235

Hossain, M.M. and Chowdhury, S.A. (2014). Pattern And Determinants Of Export Diversification In Bangladesh: An Empirical Assessment. DU Journal of Marketing. 15, 109-126.

Herrera, M.J. (2019). Chile Food Processing Ingredients. Global Agricultural Information Network. CI1905.

Hausmann, R. and Rodrik, D. (2002). Economic Development As SelfDiscovery. Journal of Development Economics. v72 (2), 603-633.

Islam, S. (2014). Product Varieties, Extensive and Intensive Margins of Trade: Evidence from Canada. Applied Econometrics and International Development. 14(2).

Jongwanich, J. (2009). Impact of Food Safety Standards on Processed Food Exports From Developing Countries. $154,1655-5252$.

Kaplinsky, R. (2011). Commodities for Industrial Development: Making Linkages Work. United Nations Industrial Development Organization.

Klinger, B. and Lederman, D. (2006). Innovation and Export Portfolios. World Bank Policy Research Working Paper 3983. 031, F10.

Latif, M. A., Rahman, M. H., and Ehasan, M. A. (2015). Agro-industrial development and sustainability in Bangladesh-A study. International Journal of Agricultural Research, Innovation and Technology, 5(2), 37 43. 
Matsuyama, K. (1992). Agricultural productivity, comparative advantage, and economic growth. Journal of economic theory. 58(2), 317-334.

McKay, J.M.A. (2007). Food industry \& economic development in the Asia Pacific. Asia Pac. 16.

Monteiro, C. A., Moubarac, J.C., Cannon, G., Ng, S.W. and Popkin, B. (2013). Ultraprocessed products are becoming dominant in the global food system. Obesity reviews. 14(2), 21-28.

Otamurodov, S., Shujin, Z.H.U. and Zhong, T. (2016). The Role of Extensive Margin and Intensive Margin in Kazakhstan's Export Growth. Ecoforum Journal. 5(2).

Pineres, S. and Ferrantino, M.J. (2000). Export dynamics and economic growth in Latin America: A comparative perspective.

Pavic, I., Galetic, F. and Piplica, D. (2016). Similarities and Differences between the CR and HHI as an indicator of Market Concentration and Market Power. British Journal of Economics, Management and Trade. 13(1), 1-8.

Siddiqui, A.H. (2018). Export Diversification and Growth in Pakistan: An Empirical Investigation from 1972 to 2015 1. Business and Economic Review. 10(1), 107-131.

Sultana, R. (2011). Pakistan-Afghan
Economic Relations: Issues and Prospects. Pakistan Horizon. 64(1), 21-37.

Syrquin, M. (1988). Patterns of Structural Change. In H. B. Chenery and T. N. Srinivasan (Eds.) Handbook of Development Economics, Vol 1. North Holland: Elsevier Science Publishers.

Türkcan, K. (2014). Investigating the Role of Extensive Margin, Intensive Margin, Price and Quantity Components on Turkey's Export Growth during 19982011.

United Nations Conference on Trade and Development (2018). Leveraging technology and trade for economic development. Economic and Social Council. B18-00824.

Vahalík, B. (2015). Analysis of export diversification development of the European Union and BRICS countries. Central European Review of Economic Issues. 18, 59-69.

Wilkinson, J. and Rocha, R. (2006). AgriProcessing and Developing Countries. Background paper. World Bank, Washington, DC.

World Bank Group and World Trade Organization. (2018). Trade and Poverty Reduction: New Evidence of Impacts in Developing Countries. World Trade Organization: Geneva. 


\section{Appendix}

Appendix 1: Specific processed food products exported from Bangladesh in 2015.

\begin{tabular}{cll} 
Categories & \multicolumn{1}{c}{ Specific products } & \multicolumn{1}{c}{ Major Importers } \\
\hline $\begin{array}{c}\text { Preserved } \\
\text { Fruits and } \\
\text { Vegetables }\end{array}$ & Nuts, prepared or preserved (13\%) & Saudi Arabia, UAE, Malaysia (73\%) \\
& Vegetables, boiling in water (10\%) & UK, USA, Canada (91\%) \\
& Semi or wholly milled rice (43\%) & Italy, USA, Saudi Arabia (65\%) \\
Flour and & Roasting cereals, corn flakes (25\%) & UAE, Saudi Arabia, Malaysia (60\%) \\
& Pre-cook Cereals (18\%) & Saudi Arabia, Singapore, Malaysia (69\%) \\
Bakery & Bread, pastry, cakes, biscuits (49\%) & Saudi Arabia, UK, USA (79\%) \\
Products & Rusks, toasted products (21\%) & India, UK, Malaysia (79\%) \\
& Sweet biscuits (12\%) & Saudi Arabia, UA, Oman (60\%)
\end{tabular}

Source: Authors' computations based on UN Comtrade data, May 2019. 
Appendix 2: Specific processed food products exported from India in 2017.

\begin{tabular}{|c|c|c|}
\hline Categories & Specific products & Major importers \\
\hline \multirow{3}{*}{$\begin{array}{l}\text { Meat } \\
\text { Products }\end{array}$} & The meat of bovine animals ( $90 \%)$ & Viet Nam, Malaysia, Indonesia (68\%) \\
\hline & Frozen edible bovine offal (4\%) & Viet Nam, Malaysia, Myanmar (83\%) \\
\hline & Sheep carcasses $(3 \%)$. & UAE, Qatar, Kuwait (78\%) \\
\hline \multirow{3}{*}{$\begin{array}{l}\text { Flour and } \\
\text { Cereals }\end{array}$} & Semi or wholly milled rice $(92 \%)$, & Iran, Saudi Arabia, UAE (32\%) \\
\hline & Broken rice $(5 \%)$ & Senegal, Indonesia, Djibouti (75\%) \\
\hline & Wheat or meslin flour (1.2\%) & USA, UAE, Qatar (58\%) \\
\hline \multirow{3}{*}{$\begin{array}{l}\text { Animal and } \\
\text { Vegetable } \\
\text { Oil }\end{array}$} & Castor oil and fractions (34\%) & China, Netherland, USA (68\%) \\
\hline & $\begin{array}{l}\text { Oilcake and other solid residues } \\
(37 \%)\end{array}$ & France, Bangladesh, Japan (35\%) \\
\hline & Fatty acids $(6 \%)$ & USA, Sri Lanka, Japan (54\%) \\
\hline
\end{tabular}


Appendix 3: Specific processed food products exported from Pakistan in 2017.

\begin{tabular}{cll}
\hline Category & \multicolumn{1}{c}{ Products } & \multicolumn{1}{c}{ Major Importers } \\
\hline $\begin{array}{c}\text { Flour and } \\
\text { Cereals }\end{array}$ & Semi-milled or wholly milled rice (84\%) & Kenya, UAE, China (31\%) \\
& Broken rice (10\%) & AFG, Indonesia, China (66\%) \\
& Wheat or meslin flour (5\%) & AFG, UAE (98\%) \\
\hline $\begin{array}{c}\text { Meat } \\
\text { Products }\end{array}$ & Carcasses bovine animals (47\%) & UAE, Kuwait (63\%) \\
& Frozen bovine carcasses (11\%) & UAE, Saudi Arabia (80\%) \\
& $\begin{array}{l}\text { Guts, bladders, and stomachs of animals } \\
(6 \%)\end{array}$ & Roman, Poland, Spain (48\%) \\
\hline
\end{tabular}

Source: Authors' computations based on UN Comtrade data, May 2019. 
Appendix 4: Specific processed food products exported from Sri Lanka in 2017.

\begin{tabular}{|c|c|c|}
\hline Categories & Products & Major Importers \\
\hline $\begin{array}{l}\text { Margarine } \\
\text { and food } \\
\text { preparation }\end{array}$ & $\begin{array}{l}\text { Food preparations }(79 \%) \\
\text { Extracts, concentrates, of tea or mate } \\
(17 \%) \\
\text { Ice cream }(1.2 \%)\end{array}$ & $\begin{array}{l}\text { China, Malaysia, Kuwait (33\%) } \\
\text { Ireland, UA, China (98\%) } \\
\text { MDV }(100 \%)\end{array}$ \\
\hline $\begin{array}{l}\text { Flour and } \\
\text { Cereals }\end{array}$ & $\begin{array}{l}\text { Wheat or meslin flour (51\%) } \\
\text { Residues of wheat (15\%) } \\
\text { Semi or wholly milled rice (9\%) }\end{array}$ & $\begin{array}{l}\text { Singapore, Thailand, Malaysia } \\
(66 \%) \\
\text { Viet Nam, Japan, UAE (95\%) } \\
\text { UAE, Australia, UK (47\%) }\end{array}$ \\
\hline $\begin{array}{l}\text { Animal and } \\
\text { Vegetables } \\
\text { Oil }\end{array}$ & $\begin{array}{l}\text { Crude coconut oil }(77 \%) \\
\text { Coconut oil and its fractions (11\%) } \\
\text { Oilcake and other solid residues (9\%) }\end{array}$ & $\begin{array}{l}\text { Germany, USA, Australia (60\%) } \\
\text { Poland, USA, Pakistan (47\%) } \\
\text { Iran, Egypt, India (49\%) }\end{array}$ \\
\hline
\end{tabular}

Source: Authors' computations based on UN Comtrade data, May 2019. 
Appendix 5: Intraregional export of processed food in South Asia, 2001-2017.

\begin{tabular}{|c|c|c|c|c|c|c|c|c|c|c|}
\hline \multirow{2}{*}{\multicolumn{2}{|c|}{$\begin{array}{l}\text { Exporting } \\
\text { countries }\end{array}$}} & \multicolumn{8}{|c|}{ Importing Countries } & \multirow{2}{*}{ Total } \\
\hline & & \multirow{2}{*}{$\begin{array}{c}\text { BGD } \\
-\end{array}$} & \multirow{2}{*}{\begin{tabular}{|l|} 
IND \\
30.6
\end{tabular}} & \multirow{2}{*}{$\begin{array}{l}\text { PAK } \\
10.6\end{array}$} & \multirow{2}{*}{\begin{tabular}{|l} 
LKA \\
3.8
\end{tabular}} & \multirow{2}{*}{$\begin{array}{c}\text { MDV } \\
0\end{array}$} & \multirow{2}{*}{$\begin{array}{c}\text { BTN } \\
55\end{array}$} & \multirow{2}{*}{$\begin{array}{c}\text { NEP } \\
0\end{array}$} & \multirow{2}{*}{$\begin{array}{c}\text { AFG } \\
0\end{array}$} & \\
\hline$\frac{\tilde{D}}{\tilde{d}}$ & 2001 & & & & & & & & & 100 \\
\hline 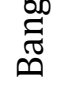 & 2015 & - & 89.3 & 0.2 & 0.2 & 4.1 & 3.4 & 0.9 & 1.8 & 100 \\
\hline \multirow{2}{*}{$\stackrel{\frac{\pi}{\sigma}}{\Xi}$} & 2001 & 31 & - & 31 & 28.5 & 1.9 & 0.2 & 4.7 & 1.7 & 100 \\
\hline & 2017 & 30 & - & 10 & 12 & 2.7 & 7.7 & 33 & 6.3 & 100 \\
\hline \multirow{2}{*}{$\frac{\Xi}{\frac{\pi}{5}}$} & 2001 & 4.2 & 0.05 & - & 1.3 & 0.1 & 0 & 0.01 & 94.2 & 100 \\
\hline & 2017 & 0.4 & 1.7 & - & 1.3 & 0.1 & 0 & 0.2 & 96 & 100 \\
\hline \multirow{2}{*}{ 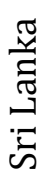 } & 2001 & 29 & 21 & 5.3 & - & 46.4 & 0 & 0.2 & 0 & 100 \\
\hline & 2017 & 2 & 60.7 & 6 & - & 30.8 & 0 & 0.02 & 0.07 & 100 \\
\hline
\end{tabular}

Source: Authors' computations based on UN Comtrade data, May 2019.

Note: BGD: Bangladesh, IND: India, PAK: Pakistan, LKA: Sri Lanka, MDV: Maldives, BTN: Bhutan, NEP: Nepal, AFG: Afghanistan. 
Appendix 6: List of processed food products according to ISIC and SITC classification.

\begin{tabular}{|c|c|c|c|c|}
\hline No & Products & SITC & $\begin{array}{l}\text { Name of Products } \\
\text { category in ISIC }\end{array}$ & ISIC \\
\hline 1 & Meat Product & $\begin{array}{l}01+41131+29192+29193+ \\
29111+29116+29199+0913+ \\
41132+41133+41134+41139+ \\
08141\end{array}$ & $\begin{array}{l}\text { Slaughtering, preparing } \\
\text { and preserving meat }\end{array}$ & 3111 \\
\hline 2 & Dairy products & $\begin{array}{l}02+59221 \text { less } 025 \text { except } \\
0252\end{array}$ & $\begin{array}{l}\text { Manufacture of dairy } \\
\text { products }\end{array}$ & 3112 \\
\hline 3 & $\begin{array}{l}\text { Processed fish } \\
\text { products }\end{array}$ & $371+29194+4111+372$ & $\begin{array}{l}\text { Canning, preserving and } \\
\text { processing of fish, } \\
\text { Crustacea and similar } \\
\text { foods }\end{array}$ & 3114 \\
\hline 4 & $\begin{array}{l}\text { Preserved } \\
\text { Fruits and } \\
\text { vegetables }\end{array}$ & $\begin{array}{l}0546+0561+0565+0586+0583 \\
+0589+0585\end{array}$ & $\begin{array}{l}\text { Canning and preserving of } \\
\text { fruits and vegetables }\end{array}$ & 3113 \\
\hline 5 & $\begin{array}{l}\text { Margarine and } \\
\text { food } \\
\text { preparation }\end{array}$ & $\begin{array}{l}098+071+59222+59212+5922 \\
5\end{array}$ & $\begin{array}{l}\text { Manufacture of food } \\
\text { products not elsewhere } \\
\text { classified }\end{array}$ & 3121 \\
\hline 6 & $\begin{array}{l}\text { Flour and } \\
\text { cereals }\end{array}$ & $\begin{array}{l}042+046+047+048+0564+081 \\
2\end{array}$ & Grain mill products & 3116 \\
\hline 7 & $\begin{array}{l}\text { Animal oil and } \\
\text { vegetable oil }\end{array}$ & $\begin{array}{l}42+43+0813+51217+2239+09 \\
14\end{array}$ & $\begin{array}{l}\text { Manufacture of vegetable } \\
\text { and animal oils and fats }\end{array}$ & 3115 \\
\hline 8 & $\begin{array}{l}\text { Sugar and } \\
\text { molasses }\end{array}$ & $0611+0612+0619+0615$ & $\begin{array}{l}\text { Sugar factories and } \\
\text { refineries }\end{array}$ & 3118 \\
\hline 9 & $\begin{array}{l}\text { Coffee extract } \\
\text { and chocolate }\end{array}$ & $0620+08192+072+0730+0582$ & $\begin{array}{l}\text { Manufacture of } \begin{array}{r}\text { cocoa, } \\
\text { chocolate, and sugar } \\
\text { confectionery }\end{array} \\
\end{array}$ & 3119 \\
\hline 10 & $\begin{array}{l}\text { Bakery } \\
\text { production }\end{array}$ & $0488+0483+04841+04842$ & $\begin{array}{l}\text { Manufacture of bakery } \\
\text { products }\end{array}$ & 3117 \\
\hline 11 & Beverage & $1110+112+08194$ & $\begin{array}{l}\text { Soft drinks and carbonated } \\
\text { waters industries/ } \\
\text { Wine industries }\end{array}$ & $\begin{array}{c}3132+ \\
3134\end{array}$ \\
\hline
\end{tabular}

